w Żytomierzu), ale także o wydarzeniach, takich jak narodziny pięcioraczków na Jeżycach (16 maja 1786), które zmarły, były bowiem wcześniakami, co przy ówczesnym stanie medycyny równało się z minimalnymi szansami na przeżycie.

Wydawnictwo uzupełnione zostało cennymi aneksami: „Porządek osób Zgromadzenia” z 1781, zawierającymi dane na temat nauczycieli, „Księga zdań o postępkach uczniów toż egzaminów odprawianych i zapisanych", z której wyłaniają się sylwetki najzdolniejszych absolwentów poznańskiej szkoły. Książkę zamyka indeks zawierający krótkie notki biograficzne, dotyczące uczniów i profesorów Szkoły Wydziałowej Poznańskiej.

Krzysztof Ratajczak

\title{
Gawlik Stanisław, Grzegorz Piramowicz - idee - slowa - czyny, Opole 2006, ss. 164
}

Omawiana publikacja wyszła spod pióra znanego polskiego historyka wychowania, autora kilku znaczących prac z zakresu historii oświaty i myśli pedagogicznej Profesora Stanisława Gawlika ${ }^{1}$ Książka ma formę interesująco skonstruowanej biografii historyczno-pedagogicznej. Na jej strukturę składają się oprócz „Wstępu”, cztery rozdziały, „Zakończenie”, „Wybrana literatura”, „Spis fotografii”, „Indeks nazwisk” i „Indeks miejscowości". Treść publikacji koncentruje się przede wszystkim wokół idei głoszonych przez Piramowicza oraz jego działalności oświatowej i społeczno-oświatowej. Podstawą rekonstrukcji poglądów pedagogicznych tego myśliciela stały się jego publikacje. W ich ocenie zaś, Autor posiłkował się ustaleniami znawców dorobku Komisji Edukacji Narodowej (KEN) i edukacji w epoce Oświecenia, m.in. Kaliny Bartnickiej, Kamilli Mrozowskiej, Czesława Majorka i innych.

Rozdział I pt. „Grzegorz Piramowicz - przedstawiciel polskiego oświecenia” (s. 15-59) ukazuje jego drogę nie tylko do stanu kapłańskiego, ale i kształtowania się tego duchownego jako działacza oświatowego. Po przedstawieniu najważniejszych etapów jego życia w pracy znajdujemy sporo informacji o działalności Piramowicza w Komisji Edukacji Narodowej. W tej części książki wyeksponowane zostały jego zasługi jako redaktora ustaw, korespondenta z zagranicą z ramienia KEN, twórcy przepisów i wizytatora szkół. W zakończeniu rozdziału jest mowa o jego działalności duszpasterskiej. Rozdział II zatytułowany „Ogólna charakterystyka twórczości piśmienniczej Grzegorza Piramowicza" (s. 61-82) stanowi omówienie pisarstwa księdza w dwóch okresach, tj. przed powstaniem KEN i po zaangażowaniu się Piramowicza w działalność Komisji, z wyraźnym zasygnalizowaniem odmienności form pisarskich i tematyki

\footnotetext{
${ }^{1}$ S. Gawlik jest autorem m.in. takich prac: Dziedzictwo pedagogiczne Klementymy z Tańskich - Hoffmanowej, Opole 1995; Dzieje myśli pedagogicznej na Śląsku, Warszawa-Wrocław 1990; Dzieje ksztakcenia nauczycieli na Ślquski Opolskim, Opole 1979.
} 
w wymienionych okresach. Autor poddał dokładnej analizie twórczość pedagogiczną. Najwięcej miejsca zajmuje omówienie chyba najbardziej znanego dzieła Piramowicza pt. Powinności nauczyciela oraz takich prac, jak: Wymowa i poezja i Nauka obyczajowa dla ludu. Autor ksiazżki zaznacza jednak, że twórczość pedagogiczna tego przedstawiciela polskiego oświecenia jest bardzo zróżnicowana, obejmuje bowiem wiersze, listy, instrukcje, mowy, polemiki, przekłady, uniwersały, pisma urzędowe, obwieszczenia, podręczniki, programy szkolne, a nawet piosenki dla ludu. Przy czym istotne w twórczości Piramowicza jest to, iż starał się on w swoich pracach połączyć idee oświatowe Zachodu $\mathrm{z}$ rodzimą refleksją na tematy edukacyjne.

W kolejnych rozdziałach (trzecim i czwartym) znajdujemy analizę poglądów pedagogicznych duchownego. I tak rozdział III „Społeczność szkolna w myśli pedagogicznej Grzegorza Piramowicza" (s. 63-115) traktuje o nauczycielach, uczniach i rodzicach jako najważniejszych elementach składowych społeczności szkolnej. W tym kontekście przedstawiona została istota i specyfika szkoły parafialnej okresu oświecenia. Ostatni, IV rozdział "Kierunki wychowania wszechstronnego" (s. 117-145) prezentuje poglądy pedagogiczne duchownego $\mathrm{z}$ wyraźnym podkreśleniem jego myśli na temat wychowania moralnego, patriotycznego, wychowania do pracy i wychowania fizycznego. Jednak, zdaniem Autora książki, nie we wszystkich koncepcjach zostały wyraziście uwypuklone najważniejsze idee wychowawcze, jak chociażby w wychowaniu patriotycznym. Wynikało to jednak ze specyfiki sytuacji społeczno-politycznej Polski, która G. Piramowiczowi była doskonale znana. Analiza tych poglądów sprawia, że G. Piramowicz jawi się jako myśliciel, który - prezentując określone poglądy pedagogiczne - uwzględnia dorobek europejskiego oświecenia, ale i wplata w swoje koncepcje rodzime pierwiastki uwzględniając sytuację społeczno-polityczną.

W „Zakończeniu” (s. 147-152) pracy, poza zaakcentowaniem najważniejszych idei oświatowych i pedagogicznych dotyczących szkoły i koncepcji wychowania omawianego duchownego i pedagoga, Autor ustalił, w jaki sposób dokonania G. Piramowicza zyskały uznanie polskiego społeczeństwa, podając przykłady nadawania jego imienia placówkom oświatowym i ulicom polskich miast. S. Gawlik przekonuje także czytelników, iż dzieło G. Piramowicza powinno być upowszechniane, pisząc: „Życie tej wyrazistej osobowości, będącej symbolem epoki oświecenia, budującej wizerunek KEN, rzetelnie przedstawiającej sprawy oświaty, to dzieje człowieka czystego moralnie, zawsze gotowego słuchać innych i skutecznie działać. Przepojony idealnym duchem edukacyjnym, pełen wewnętrznego ciepła mimo powszechnie gnieżdżącego się moralnego zła, pozostał do dziś trwałą busolą wartości" (s. 151).

W recenzowanej pracy postać Grzegorza Piramowicza oraz głoszone przez niego poglądy i główne kierunki aktywności ukazane zostały na tle przemian dokonujących się w epoce oświecenia, z nakreśleniem skrótowo cech charakterystycznych tej epoki, zwłaszcza w obszarze oświatowym i społeczno-politycznym. Umiejętnie wplecione wątki historyczne w biografię G.Piramowicza dopełniają się nawzajem, powodując tym samym lepsze zrozumienie życia i działalności tego zasłużonego duchownego i pedagoga.

Książka jest warta lektury co najmniej z kilku powodów. Przede wszystkim trzeba się zgodzić z Autorem, że postać Grzegorza Piramowicza zasługuje na przypomnienie, ze względu na jego wkład w dorobek polskiego oświecenia w zakresie edukacji. Należy tak- 
że zwrócić uwagę na walory warsztatowe omawianej publikacji, tj. przejrzystą konstrukcję i styl pisarski Autora, piękny język. To sprawia, że książkę czyta się fragmentami jak powieść historyczną, a raczej powieść biograficzną, co stanowi zasługę Autora w popularyzacji historii myśli oświatowo-wychowawczej. I wreszcie wypada powiedzieć i to, że Profesor Stanisław Gawlik swoją książką powiększył dorobek historiograficzny dotyczący dziejów oświaty jezuickiej i pedagogiki ignacjańskiej.

Władysław Szulkiewicz

\section{Herbart znany $i$ nieznany. $W$ dwusetnq rocznicę wydania Pedagogiki ogólnej, praca zbiorowa pod red. Jana Piskurewicza i Dariusza Stęp- kowskiego SDB, Wydawnictwo Salezjańskie, Warszawa 2006, ss. 216}

Jest to pozycja zbiorowa, która opublikowana została w roku 2006, tj. w dwusetną rocznicę wydania epokowego dzieła Johanna Friedricha Herbarta (1776-1841) pt. Pedagogika ogólna wywiedziona z celu wychowania (1806). Ten wybitny klasyk myśli pedagogicznej i filozoficznej, który dał początek pedagogice jako naukowej teorii wychowania i kształcenia, z pewnością zasłużył sobie na refleksję naukową nad nim i nad jego dorobkiem. Refleksja ta stała się przyczynkiem do zorganizowania przez Zespół Katedry Historii Wychowania w Instytucie Pedagogiki im. Św. Jana Bosko Uniwersytetu Kardynała Stefana Wyszyńskiego w Warszawie konferencji naukowej poświęconej J. F. Herbartowi, której pokłosiem jest niniejsza publikacja.

Artykuły zaprezentowane w książce koncentrują się na szeroko rozumianej analizie Pedagogiki ogólnej oraz myśli jego twórcy.

Publikacja podzielona została na trzy części, z których każda stara się ukazać Herbarta $\mathrm{i}$ jego dorobek w sposób odmienny.

Część pierwsza, zatytułowana Kontrowersje wokót Herbarta i jego myśli, przedstawia zagadnienia dotyczące całokształtu myśli filozoficznej i pedagogicznej J. F. Herbarta.

W pierwszym artykule autorstwa Dietricha Bennera znajdujemy analizę wizji szkoły, jej teorii i krytyki w kontekście mało znanych w Polsce wypowiedzi Johanna Friedricha Herbarta, a także skłaniającą czytelnika do refleksji wypowiedź o aktualności herbartowskiej krytyki szkoły.

W tekście Teresy Hejnickiej-Bezwińskiej zawarte są zagadnienia dotyczące kwestii naukowości pedagogiki w modelu, jaki przyjął i rozwinął w XIX w. Herbart. Autorka trafnie ukazuje w nim herbartowską pedagogikę w jej akademickich strukturach, oferującą tworzenie wiedzy o rzeczywistości edukacyjnej i oświatowej, wykorzystującą nie tylko zagadnienia pedagogiki, lecz również inne nauki społeczne, szczególnie psychologię i socjologię.

Maria Boużyk stara się poszukać odpowiedzi na pytanie o przynależność filozofii Herbarta do jednego $\mathrm{z}$ dwu podstawowych nurtów myślenia, tj. realizmu, czy idealizmu. Dokonując wnikliwej analizy, autorka dostrzega drożność filozofii herbartowskiej 